44-1 | 2019

Nature, environnement et écologie politique en Irlande

\title{
Conor McNamara, War and Revolution in the West of Ireland: Galway, 1913-1922
}

\section{Bernard Kelly}

\section{OpenEdition}

1 Journals

\section{Édition électronique}

URL : https://journals.openedition.org/etudesirlandaises/7404

DOI : $10.4000 /$ etudesirlandaises. 7404

ISSN : 2259-8863

\section{Éditeur}

Presses universitaires de Caen

\section{Édition imprimée}

Date de publication : 14 novembre 2019

Pagination : 159-160

ISBN : 978-2-84133-945-7

ISSN : 0183-973X

\section{Référence électronique}

Bernard Kelly, "Conor McNamara, War and Revolution in the West of Ireland: Galway, 1913-1922 », Études irlandaises [En ligne], 44-1 | 2019, mis en ligne le 14 novembre 2019, consulté le 25 novembre 2022.

URL : http://journals.openedition.org/etudesirlandaises/7404; DOI : https://doi.org/10.4000/ etudesirlandaises.7404

\section{(c) (i) (2) (2)}

Creative Commons - Attribution - Pas d'Utilisation Commerciale - Partage dans les Mêmes Conditions 4.0 International - CC BY-NC-SA 4.0

https://creativecommons.org/licenses/by-nc-sa/4.0/ 
by in this loop of infinite replay and [reuse] them in an act of creative recycling" (p. 187), rather than indulging in self-pity on the brink of nothingness, should be considered a "strategy for managing the void" (p. 186). This brilliant book, which itself involves creative reiterations, casts light on Banville's mature treatment of exquisitely recycled literary concerns in his more recent fiction, urging the reader to delve further into his work and again admire its beautifully crafted simulacra.

Julie LECAS

\section{Conor McNamara, War and Revolution in the West of Ireland: Galway, 1913-1922, Dublin, Irish Academic Press, 2018, 243 p.}

The history, and historiography, of the Irish revolutionary period is inevitably dominated by events in Dublin and Munster. While this is understandable, an overfocus on these two obscures the situation in the other parts of the country. Given that the revolution was driven by an assortment of factors which varied from place to place, regional analysis offers the best way to examine it. Conor McNamara's book follows the template set by David Fitzpatrick and Marie Coleman and attempts to rebalance the picture by focusing on a specific area, examining both the causes and course of the revolution there. The result is something of a hybrid, bringing together an analysis of long-term underlying trends with the events within the relatively short timeframe of the Rising and war of independence itself.

Galway was a microcosm of how local and national factors combined to drive the revolution in Ireland. McNamara devotes a great deal of time to the land issue in Galway, where agrarian agitation fuelled violence long before 1919. The county is depicted as a conservative, poor and divided society, in which people's lives were dominated by the struggle to survive, and one in which life in the Irish-speaking West was very different from the affluent East. A large number of families attempted to eke out a living on small plots of between one and five acres, meaning that land hunger was widespread and drove intimidation, attacks on animals, arson, assaults and murder against large farmers, landlords, agents and graziers. This context is important because Galway was invariably classified as being a "disturbed" county by the police but, as McNamara suggests, there was good reason for Galway farmers to be dissatisfied. The outbreak of war in 1914 and the Irish Parliamentary Party's support split the Volunteers across the county as well as the Gaelic Athletic Association (GAA), with clubs in the south of the county joining the short-lived National GAA from 1915 to 1918. Deep fissures also existed between rural and urban Galway, which was reflected in the spread of attacks on British forces between 1919 and 1921, which were "resolutely rural". The IRA did not have much support in either Galway city or the larger towns, illustrated by the fact that military officers remained part of the social scene 
throughout the period and the Galway Races went ahead without interference in 1920 and 1921. McNamara is critical of the Volunteers in Galway, describing them as "often disorganised and frequently incompetent" in comparison to the IRA in other parts of the country. However, he does not hold back in his condemnation of the British forces either, accusing them of a campaign of assassination against leading Galway republicans, few of whom actually died in action. A series of killings by the army and police in 1920 and 1921, in which men were bundled out of their homes and later found dead, sometimes after torture, curbed IRA activity, but random murders of civilians turned public opinion against British rule and stimulated further resistance.

There is a welcome chapter on the effect of the revolution on Protestants in Galway which correctly rejects Peter Hart's thesis of ethnic cleansing and instead suggests a mixture of the breakdown of law and order combined with economic resentment inspired boycott, intimidation and violence against Protestants, particularly after the Truce of July 1921. The Protestant population of the county was already in decline well before the revolution, as was the population of the county as a whole, through relentless post-Famine emigration. Also welcome is the effort to illustrate the role played by women in the revolution, both inside and outside Cumann na mBan, although this inevitably suffers from the lack of records left behind and the low regard many contemporaries had for women's involvement. Relying on lists of Cumann na mBan to gauge female participation is not enough, as McNamara points out. The level of detail on local Volunteer companies is impressive, but there are some surprising omissions. For instance, while Liam Mellows' actions during the Rising are described in detail, once he flees to America in 1916 he largely vanishes from the work, and the longer-term effects of his intensely personal command in Galway are not analysed - an important factor, considering that the Volunteers in Galway idolised him, as the Witness Statements in the Bureau of Military History make clear. The book ends on a pessimistic note, stating that many of the political elite who were pushed aside in 1918, such as Máirtín Mór McDonagh, made a comeback in the 1920s and the people who participated in the revolution were forgotten. Further local examinations of the revolution in Ireland will ensure that they are not.

Bernard Kelly

\section{Agnès Maillot, L'IRA et le conflit nord-irlandais, Caen, Presses universi- taires de Caen, 2018, 346 p.}

L'autrice, enseignante-chercheuse à Dublin City University, avait déjà publié un ouvrage sur le même sujet en 2001 (IRA: les républicains irlandais aux Presses universitaires de Caen). Or, depuis cette époque, des changements considérables 